Article

\title{
African by Exposure: Caregivers, Madness, and the Contagious Other in García Márquez's Of Love and Other Demons and Rhys's Wide Sargasso Sea
}

\author{
Meredith L. Harvey \\ Department of English, George Williams College of Aurora University, Williams Bay, WI 53191, USA; \\ mharvey@gwc.aurora.edu
}

Received: 19 November 2018; Accepted: 15 January 2019; Published: 18 January 2019

\begin{abstract}
The following article discusses Gabriel García Márquez's Of Love and Other Demons and Jean Rhys's Wide Sargasso Sea. Specifically, this article will discuss the parallel ways that two novels critique the nature of postcolonial development in the Caribbean, particularly in regard to race and hybridity. Within the novels, the child protagonists and their African/black creole nursemaids follow surprisingly similar plots, though the settings, contexts, and styles of the two texts differ greatly. In these two novels while the white protagonists both die because of their hybrid navigation of their environment, their nurse/mothers survive, largely because of their maintenance of African practices. In many ways, the nurse mothers' survival and attempts to heal their charges present potential antidotes for the "disease" produced by slavery. The purpose of this paper is to explore those parallel developments in plot, and to look at the ways the two texts disrupt and reinforce colonial hegemonic norms through their depictions of both the nurses and their charges.
\end{abstract}

Keywords: García Márquez; Jean Rhys; Postcolonial; Caribbean Literature

"In the Caribbean, to which I belong, the overflowing imagination of the black African slaves was mixed with that of the pre-Columbian natives and then with the fantasies of the Andalusians and the Galicans' worship of the supernatural". (qtd in Vega Gonzalez para 3)

While problematic and colonizing in its rhetoric of "imagination" and "fantasies," García Márquez's statement regarding the mixture of beliefs in the Caribbean emphasizes the intersections of cultures within the postcolonial New World. Puri (2004) cites the unique capacity that the Caribbean opens up for colonial studies and particularly studies of hybridity due to its role as the first of the European adventures into colonialism, its role in the transatlantic slave trade, and the influx of multiple cultures that flourished and developed in this early globalized space. Furthermore, Puri (2004) makes a case for "discourses of cultural hybridity ... as strategies for constructing/deconstructing, and reconfiguring trans/national imaginaries" within the Caribbean, but Puri (2004) also warns about the dangers of any single narrative of cultural hybridity and suggests that scholars "interrogate" the postcolonial and recognize the "cautionary lessons" that Caribbean discourses of hybridity relay (pp. 1-3). In the following essay, I will look how García Márquez (1995) and Rhys (1999a) use such strategies to create and critique hybrid Caribbean identities through their depictions of the white creole protagonists and the black creole nurses of Of Love and Other Demons and Wide Sargasso Sea.

Of Love and Other Demons, a piece of magical realism written in Spanish by a male author of mixed descent from Colombia, and Wide Sargasso Sea, a postmodern text written in English by a British white creole woman from the Commonwealth Caribbean Island of Dominica, differ greatly in style; however, more striking are their similarities in themes, characters, politics, and plotlines. Both Caribbean texts critique slavery and subsequent racial constructions through the story of a white creole daughter 
of plantation slave owners in a state of economic, physical, and mental decline; both texts utilize physical and mental illness as metaphor for slavery's destruction of society; both texts tell the story of an aristocratic child abandoned by her mother and raised by a powerful woman practitioner of the syncretic religions ${ }^{1}$ of the Caribbean; both texts critique colonial powers, who see the girls' attachment to the African culture in which they were raised as mental illness; and finally, both young women die as those powers attempt to "cure" the women of those African influences that empower/infect them.

The following paper discusses the ways that the parallel texts both disrupt and reinforce colonial hegemonic norms through their depictions of the nurses and their charges. Such an exploration develops in response to Handley (2004) call to examine the ways in which the shared histories of oblivion in the global south allow for distinct reimaginings of postcolonial narratives and identities in New World literatures. In the Caribbean, in which these two novels take place, the oblivion of the African world through slavery and the reimagining of Caribbean identity in light of that oblivion take center stage. While the white protagonists of the novels both die because of their adoption of African practices and identities, their nurses remain powerful because of their maintenance of African practices in conjunction with their adoption/adaptation of Catholic practices. Through the nurses' powerful hybridity $^{2}$ and attempts to heal their charges, the authors construct a Caribbean hybrid identity that might act as a potential antidote for mental and physical illness, both products of slavery for the white creoles of the novels. These depictions of a hybrid Caribbean narrative critique assumptions of superiority in colonial cultures and disrupt binaries of racial fixity necessary for the maintenance of colonial authority; however, the contrast between the survival of the powerful hybrid black creole and the death of the racially subversive white creole implies that racial and cultural fixity can only be successfully subverted through a hegemonically inscribed "upward" racial mobility, for the black creole nurses can disrupt the colonial narrative through their ability to reimagine an identity that adopts/adapts the Catholic traditions and other cultural norms of the white creole, but the white creole's adoption of African practices and attempts at blackness can lead only to death. In light of these contrasting narratives, the authors critiques of colonialism fall short and merely show that the colonial society wants no 'cure' for the illness they have created in their postcolonial world-and while the Other ${ }^{3}$ needs no cure, she cannot progress without adopting/adapting to the diseased culture.

\section{A Soul That Was Healthy and at Peace}

The primary action in Of Love and Other Demons takes place in the port town of Cartagena de Indias, in New Granada, now Colombia. The setting provides García Márquez with the context to explore questions of transatlantic postcolonial exchange at the peak of the slave trade during the 18th century ${ }^{4}$. As Penuel (1997) notes, Of Love and Other Demons is "García Márquez's most sustained engagement with colonialism" (p. 39), but in particular it is a "sustained engagement" with the colonial society built around the slave trade. The opening paragraph of the novel sets the scene as "an ash gray dog" bites four people, three of whom were "black slaves." García Márquez does not name the race of the fourth victim, the protagonist 12-year-old Sierva María de Todos de Los ángeles, but her status as a daughter to a Marquis allows the reader to assume she is of European descent, even within the first paragraph. As the paragraph continues, the reader finds that Sierva María has been taken

1 Syncretic religions of the Caribbean are those religions that combine beliefs and practices of African and/or indigenous traditions with those of European traditions. Santería, Obeah, Voodoo, and Candomblé are examples of such religions.

2 Hybridity in this context embodies Bhabha (2004) reference to cultural hybridity across postcolonial cultures as "the sign of productivity of colonial power" and "the revaluation of the assumption of colonial identity through the repetition of discriminatory identity effects" (p. 112).

3 Throughout this paper, the terminology of the "Other" refers to that invoked in Said (1978) Orientalism, in which he emphasizes the articulation of the cultural/racial/and colonial Other as part of the process of European colonization.

4 According to the $\mathrm{BBC}$, at its peak at the end of the 18th century, over 70,000 slave annually were transported through the Transatlantic slave trade ("The Atlantic Slave Trade", in The Story of Africa-Slavery. London: BBC World Service. Available online: http://www.bbc.co.uk/worldservice/africa/features/storyofafrica/9chapter4.shtml, accessed on 3 November 2018). 
to the slave market by a "mulatta" to buy "a string of bells for her twelfth birthday" (p. 7). García Márquez's setting of the novel in a racially diverse context of the slave port orients the reader within Sierva Maria's racially hybrid space, but also points to the process of oblivion and reimaging that occurs as a result of the transatlantic slave trade.

In his description of the slave market, García Márquez critiques the slave trade and the racial constructions that both produced and were produced by it. The narrative describes incompetent slave traders who attempt to conceal a boatload of dead slaves, who are first thought to have carried "some African plague" and later found to have died of "food poisoning." The slave traders' attribution of disease to the African Other reveals assumptions of cultural superiority-even while in truth the slave owners' mismanagement causes this illness. The disconnect between the unlikely, but assumed, narrative of African illness and the dismissed, but likely, case of food poisoning suggests that the cause of all "illness" of Cartegena may indeed be the slave owners themselves. Interspersed with the description of the market, the narrative introduces us to Sierva Maria's absent, drug addled, and corpulent mother Bernarda who both "broke wind in pestilential explosions that startled the mastiffs" and was quite "astute ... in the slave trade" (p. 9). With this juxtaposition, García Márquez marks the slave trade as one source of Bernarda's aristocratic illness based upon overindulgence. García Márquez also introduces Sierva María's father, a Marquis who does not know the date, nor that it is his daughter's birthday until he hears "the music and fireworks thundering the slaves' courtyard in honor of Sierva María" (p. 10). As Cass (2009) explains, “The recurrent portrayals of Sierva María's parents as defective citizens undercut[s] the value of the crumbling white nobility in which Sierva María would have been raised had her parents concerned themselves with her upbringing" (p. 50). Through the detached irony with which García Márquez introduces these physically, mentally and morally deteriorated slave traders, we see illness serve as metaphor for the irrational colonial narrative of racial fixity in 18th century Cartegena.

The deficiencies of the aristocracy appear more pointed in light of the description of Sierva María's nurse, Dominga De Adviento: "a formidable black woman who ruled the house with an iron fist until the night before her death," "was the link between these two worlds [of slaves and the decrepit Marquis]," and possessed "an almost clairvoyant intelligence" (p. 11). Dominga De Adviento's domestic power contrasts the inept Marquis and his "pestilent" wife. While Dominga De Adviento navigates between the two spaces, the text makes clear that she keeps order of both, for the Marquis and his wife cannot control their own minds, nor bodies, much less their household. If, as Vásquez-Medina (2013) claims, both mental and physical illness in the novel "serve to articulate the key issues of racial conflict" (p. 164), then the juxtaposition of Dominga De Adviento's wellness and Sierva María's parents' mental illness critiques the colonial belief in the historical exclusivity of European rationalism, for depictions of Domingo De Adviento's intellectual superiority deconstruct colonial logic dependent upon a binary narrative of European civility and African savagery. Furthermore, the text contextualizes the source of Dominga De Adviento's wellness within her cultural syncretism: she "became Catholic without renouncing her Yoruban beliefs, practiced both religions at the same time, at random;" and had a "soul that was healthy and at peace" (p. 11). At first glance, Dominga De Adviento's wellness appears contingent upon her simply adopting Catholic colonial religion and maintaining the religions of her ancestral West African home. Yet when such a reading considers the primary tenet of Catholicism as the acceptance of a monotheistic God, we see that Dominga De Adviento has rewritten the rules of Catholicism to be more inclusive of her own polytheistic traditions; she has not merely adopted, but adapted Catholicism and as such reimagined a religious narrative for the New World. Despite her marginalized status as slave, Dominga De Adviento's adaptation of Catholicism demonstrates a hybridity that Homi K. Bhabha defines as "the sign of the productivity of colonial power, its shifting forces and fixities" and her maintenance of Yoruban beliefs only serves to emphasize her "strategic reversal of the process of domination through disavowel" (Bhabha 2004, p. 112). 
Similarly, García Márquez's descriptions of Sierva María, emphasize both her hybridity and her wellness, and situate her in the liminal space between her parents' society and that of the slaves. As the only "free person" in this "oppressive world" of Cartegena, Sierva Maria's genetic link to the aristocracy grants her legal freedom, yet her lived experience frees her of the constraints of her parents' institutionalized illness; for she experiences life as a member of the African community. She "celebrated her birthday in her true home with her true family," danced and sang in African languages with women who "at the order of Dominga De Adviento ... had her face blackened with soot," and "hung Santería necklaces around her neck" (p. 12). Cass (2009) cites the significance of these acts as "racial subversion:" (p. 49). Sierva María adopts the African songs, the traditions of Dominga De Adviento and the other slaves, and even black face, so that she effectively abandons her born European self for her adopted African self, and in doing so subverts perceptions of cultural fixity attached to race in Cartegena society. As Cass (2009) points out, within the African community such subversions are accepted: "Dominga and the estate slaves do not regard her [Sierva María] as a racial Other ... in fact the adoptive community promotes a fluid racial worldview that operates in strict contrast with the stringent racist/racial categorization espoused by the white elite" (p. 50). Such racial subversion, in light of Sierva María's initial wellness reveals Dominga De Adviento's syncretic capabilities to heal, or least prevent illness in the white creole body. In this way, García Márquez suggests the powers of hybridity, as represented through Domingo De Adviento's syncretic practices, as an antidote to the illness of slavery.

While the narrative proceeds in a non-linear fashion, throughout the text the role of Dominga De Adviento in Sierva María's wellness and survival becomes more clear. When the Sierva María is born premature, the midwife announces that the baby will not live, so Dominga De Adviento "promised her saints that if they granted the girl the grace of life, her hair would not be cut until her wedding night;" the baby's first cries occur only after the promises are made (p. 42). In this moment, Dominga De Adviento performs the role of surrogate mother as she "gives birth" to the syncretic child through her promises to the saints. When shortly thereafter, both father and mother reject the child, Dominga De Adviento "suckled her, baptized her in Christ and consecrated her to Olokun, a Yoruban deity" (p. 42). Dominga De Adviento sustains Sierva María's physical nourishment, which the ill Bernarda will not and cannot provide through nursing, and Dominga De Adviento saves Sierva María's immortal soul through her baptism and consecration. Through this portrayal of Sierva María's wellness, the text disrupts the narrative of religious superiority and its related racial categorization, both necessary to the maintenance of slavery, for Dominga De Adviento's capabilities as mother and syncretic spiritual guide make her not only equal in humanity to her master, but superior in her ability to provide Sierva María the tools necessary to navigate the Caribbean world.

After the death of Dominga De Adviento, García Márquez describes Sierva María's decrepit parents' irrational attempts to improve upon Sierva María's condition, despite her demonstrated wellness. Throughout this process, Bernarda reenacts the colonial acts of slavery upon Sierva María, as she removes Sierva María from her home and replaces her African languages and songs with "Peninsular Spanish" and western musical instruments (p. 44). During this colonization, García Márquez's narrative shows contempt for societal assumptions of improvement of the Other through Bernarda's irrational fears of the imagined Other within her daughter. This critique reaches its apex at the moment Bernarda decides to return her daughter to the slave quarters: "when Bernarda woke ... dying of thirst brought on by the excesses of cacao and found one of Sierva María's dolls at the bottom of a large water bottle, she did not think it was really a simple doll floating in the water, but ... a murdered doll" (p. 45). Despite the known source of her own illness in the excesses of cacao, Bernarda conflates illness with the presence of the Other in Sierva María, as she assumes her daughter has cast an "African spell" on her. Through the displayed irrationality of Bernarda's actions as mother and colonizer, this passage critiques paternal justifications for colonization as salvation and subverts hegemonic categorizations of the rationale European mind in contrast to the irrational Other. 
In a similar fashion, García Márquez demonstrates the Marquis' misguided attempts to heal Sierva María after she is bitten by the rabid dog. After putting the house in order (and thus taking over the now deceased Dominga De Adviento's role), he takes Sierva María and declares, "From this day forward the girl lives in the house... She has only one family and that family is white" (p. 25). In his emphasis on racial difference in his removal, he demonstrates a belief that a cure might be found in his disruption of the racial subversion accomplished the by the girl's African education. When three months later, the Marquis suspects his daughter had contracted rabies, he subjects his daughter to the "healing" of "physicians, barber-surgeons, pharmacists, magical healers and masters of sorcery" (p. 50). The Marquis' failed efforts to heal through indigenous, African, and colonial practitioners, despite his initial colonization of his daughter, reveals an inauthentic navigation or awareness of those liminal spaces, their intersections, and the very "cures" they offer. Sierva María's fever subsides, but due to his lack of authority in any of the cultural realities of his world, these acts of healing continue, and they literally open the wound, and causing Sierva María to act out in pain construed as madness, thus confirming her contraction of rabies. The Marquis fails in his attempts to improve Sierva María to the fixed racial status of her aristocratic identity, but through his creation of her illness, he solidifies her marginal status; for as Vásquez-Medina (2013) argues, the connections made between rabies, madness, and possession ... accomplish another form of "othering" (p. 169). Through this process Sierva María's white creole body becomes a space upon which García Márquez critiques the process of slavery, for colonial society, as represented by her father, first creates the Other then denies the Other power and agency based upon its newly created status. Like his wife's efforts to educate their daughter, the Marquis' circular, irrational, ill-informed, and hypocritical attempts to cure Sierva María, emphasize the irrationality of the colonial act, as well as the manufactured nature of the fixed racial binaries upon which the act depends.

Sierva María's parents' attempts to cure her from her perceived marginality ironically result in her doubly marginalized status, which ensures her death at the hands of the Church. When a Bishop convinces the Marquis that Sierva María's "howling gibberish of idolaters" indicates that she suffers from not only rabies, but demonic possession, Sierva María again faces removal (p. 55). This time she is removed from both surrogate and biological family when the Marquis relinquishes her to the absolute authority of the Church at the Convent of Santa Clara. As Utley (2011) points out, once in the Convent "the underlying cause of her madness is implicitly linked to her African formation, a situation that the Church, in typical early modern fashion, associates her with demonic possession and madness-the Other has transgressed her person, her identity" (p. 84). In contrast to this manufactured illness, the Bishop is a man "assailed by poor health" and sitting in "a sedan chair carried by government dignitaries" because he has trouble walking likely caused by his "huge body" (p. 52). As Vásquez-Medina (2013) points out, "Illness adds to material decline of city, which is linked to the oppressive moral climate" (p. 164), which in this case has rendered the Bishop both physically and morally corrupt in this colonial space-and thus, unlike Dominga De Adviento, incapable of saving Sierva María's body or soul. The text contrasts the Bishop's authentic illness to Sierva María's fabricated illness and suggests the inauthentic nature of the justification for colonization as salvation for the Other, thus emphasizing the colonial church's hypocritical participation in murder justified as salvation throughout the New World. The Church's inauthenticity and inability to heal Sierva María also further emphasizes García Márquez's idealized portrayal of Dominga De Adviento's reimagined syncretic religious narrative as a source of healing in the New World.

On the first day of Sierva María's exorcism, the nuns remove her necklaces, wash her, and chop off her hair in a "ritual of a prisoner condemned to death" (p. 128). The Church's removal of Sierva María's hair attempts to strip her of her African identity and ties to Dominga De Adviento. In effect, the Church's removal of her hair breaks the promise Dominga De Adviento made to her syncretic saints to ensure wellness for the authentically ill and premature infant. In contrast to Dominga De Adviento, who demonstrates faith through her prayers, the Church lacks faith in God's ability to save both body and soul, so through cutting her hair, they sacrifice the body in order to save the soul. 
At the hands of the Church, such salvation will result in Sierva Maria's death and her earthly ties to Dominga De Adviento's life giving presence. In his condemnation of the Church, García Márquez destabilizes the colonial narrative through what Penuel (1997) cites as Dominga De Adviento's religion that is in the "service of life" in contrast to the Church's "religion of death" (p. 42). Dominga De Adviento's syncretic faith and healing disrupts the fixity of the colonial narrative of salvation through Christianity, and in such Dominga De Adviento's idealized hybridity presents a productive alternative to the binaries of the colonizer. But Sierva María's disruption of those same binaries through her wellness in the adoption of African ways, proves unsustainable in the white creole body. Utley (2011) posits that ultimately García Márquez's text represents the failure of hybridity in the white creole: "with the Church's medicine, Sierva Maria's subjectivity, and society itself, may be saved and the Other separated from the European hegemonic self" (p. 84). This failure conflicts with idealized portrayal of Dominga De Adviento and suggests the self-defeating nature of the white creole's resistance to hybridity. While such a fatalistic view of the colonial power's adherence to racial and cultural fixity complements García Márquez's narrative trajectory, it does not address his final effort at subversion in the closing lines of the novel.

In a final act of subversion of the "truth" of colonial fixity, in death, Sierva María's hair that had been promised to Dominga De Adviento's syncretic saints, "gushes like bubbles from her shaved head" (p. 147). This singular confirmed supernatural occurrence in the novel implies the subversive power of Dominga De Adviento's syncretism over the Church's absolute truth in life and death. While Sierva María's racial subversion through the adoption of African culture subverts hegemonic rules of society, Dominga De Adviento's prayers subvert the absolute power of the Church that defines that society. As Sierva María's hair gushes, readers know that the prayers of Dominga De Adviento possess a strength beyond the fixity of the colonial church; these closing lines present the transcendent survival of the idealized hybrid Other in the New World. In contrast Sierva María's story implies that indeed the racial fixity of the colonial power leads only to death and annihilation, not of the Other, but of itself.

\section{The First Clue Is Obeah}

Inspired by her upbringing as a white creole woman of the Caribbean, Rhys developed the protagonist Antoinette in Wide Sargasso Sea as her postcolonial response to the "mad woman" in the attic of Charlotte Bronte's Jane Eyre. In her novel, Rhys christens Rochester's Bertha, Antoinette, and tells the story from her Caribbean perspective, as well as from the perspective of an unnamed British narrator who represents a young Rochester. While Bronte sets her novel in the early 19th century, Rhys sets her novel midcentury to emphasize the interracial relationships and conflicts that affect her protagonist Antoinette in the years just after the emancipation of Jamaican slaves. Rhys's choice to adapt the timeline in her retelling reflects her interest in the ways slavery, African influences, and racial construction play a role in the formation of Caribbean white creole identity. Indeed, the novel reimagines a white creole narrative as informed by the hybrid culture founded through dynamic power relations between Africans, their black creole descendants, and the white creoles. In her formation of a Caribbean narrative, Rhys depicts the white creole's positioning as one that situates her as liminal Other in opposition to the British colonial powers that occupy the island at the time of emancipation; yet Rhys also explores the black creole as a racialized Other who both mirrors and contrasts the white creole protagonist. As she struggled to write the story of this protagonist, Rhys wrote a note in a journal that emphasizes the significance of syncretism and religious hybridity, in her formation of this narrative: "The first clue is Obeah"

5 Obeah refers to methods of healing and casting of spells for evil/good. The practices of Obeah originated in Africa and are currently practiced in Jamaica and other areas of the Caribbean. Generally, practitioners of Obeah do not name it such, largely due to the stigma of the name due of fears of the African religions in the New World (Paton 2015). 
Rhys, like García Márquez in Of Love and Other Demons, utilizes the failed white creole aristocratic parent to illustrate the irrationality of slavery. As daughter of a member of the flailing plantation society, Antoinette is largely abandoned by her mentally ill mother Annette. As Antoinette's narrative explains, "I [the child Antoinette] was useless to her ... old enough to take care of myself ... and after I knew she talked aloud to herself I was a little afraid of her" (p. 11). Antoinette's narrative, while fractured in its childlike perspective, reveals Annette's maternal deficiencies and mental instability - and further passages reveal that illness as a product of her confused identity at the conclusion of slavery. When Annette's horse, the final symbol of her plantation wealth, is poisoned by emancipated slaves near their Coulibri Estate, she states, "now we are marooned" (p. 10). In "marooned" Annette's dialogue ties their isolation as a former plantation slave-holders, to the isolation of slaves who escaped to "maroon" communities ${ }^{6}$. However, while the slaves gained freedom in their maroon colonies, Annette's condition demonstrates her failure to thrive beyond the institution of slavery. Her comparison inverts the positioning of the maroon in slavery-as Annette's marooning results in a loss of power. This inversion reveals the effect emancipation has on deconstructing and reconstructing an ambivalent white creole Caribbean identity that cannot legitimize its own power in light of the liberation of the racial Other-but through Rhys's portrayal of Annette's mental illness as context for her utterance, Rhys emphasizes the irrationality of the disempowered white creole and the irrationality of the failed institution of slavery itself. Within the novel, Rhys contrasts Annette's lack of control and capabilities to her characterization of Christophine, Annette's former slave "given" to her as a wedding present. While Annette fails to perform the role of mother to Antoinette, Christophine, like Dominga De Adviento in Of Love and Other Demons, performs the role of mother as nurse, even after emancipation. Jaising (2010) argues that while Rhys clearly critiques imperialism, Christophine's efforts to "support and defend her white mistress [Antoinette]" situate Christophine as the "good black servant," which "relies on the racialized typologies of liberal colonialist discourse" (p. 817). Similarly, Olaussen (1993) sees Christophine as reinforcing stereotypes of the "mammy" figure, a character so benevolent and/or harmless that "the contradiction of considering people less that human and then entrusting them the care of one's own children is made less apparent" (p. 73). Spivak (1985) also reads Christophine as "the good black servant" and recognizes the limits to Christophine's role in a text that focuses on the construction of the white creole identity of her charge; however, she also recognizes Christophine's willingness to contradict the narrative of the British colonial power as represented by Rochester. Despite these critical readings of Christophine as the good servant, it seems that any reading of her should acknowledge that she is rarely depicted as an obedient servant. Annette presents such a picture in her claim that "Christophine stayed with me because she wanted to stay" and "she had her own very good reasons" [emphasis mine] (p. 12). While Annette's point of view seems problematic at best given her attachment to the idealized memories of plantation society, such claims seem consistent with Christophine's willingness to challenge the white creoles surrounding her. As the racial Other, Christophine's dialogue often critiques manifestations of disempowerment. One such critique reveals the possible reasons for Christophine's choice to remain with Antoinette after emancipation: "No more slavery! ... These ones have the Letters of Law. Same thing ... jail house and chain gang new ones worse than the old ones" (p. 15). Christophine comprehends the anger of the formerly enslaved and the hegemonic restrictions in the free world of the British colonies and acts as interpreter of the marginalized space that both white creole and black creole occupy in the Caribbean. While Christophine's perception manifests Rhys's bias due

6 Bhabha (2004) draws the connections between black texts, strategies of hybridity, and maroon communities in his discussion of Houston Baker's look at Modernism in the Harlem Renaissance. Bhabha suggests the "guerilla warfare" of the maroon communities manifests within the subversive nature of these "decentered" texts (pp. 144-45). Rhys's evocative subversive word choice, when read in conjunction with Bhabha's emphasis of the maroon, demonstrates the parallels she draws between the hybrid narratives of the white and black creole populations in the Caribbean. 
to her positioning as white creole colonial subject, it also disrupts the liberating narrative of British colonialism of the 19th century.

Like García Márquez in Of Love and Other Demons, Rhys's uses the characterization of the nurse figure to explore the hybridity of the black creole, albeit her depiction does so through a less idealized lens. Rhys describes Christophine's room covered with pictures of "the Holy Family and happy death," and in such, we can see her immersion into the Catholic belief system, but Rhys also implies the maintenance of African beliefs in Christophine's practice of Obeah. Such practices reveal Christophine's resistance to the colonial narrative of a single belief system, and she like Dominga De Adviento relies on an adapted form of Catholicism as part of her syncretic powers. Christophine also speaks English, French, and Patois ${ }^{7}$, but unlike Dominga De Adviento's hybridity that assures her "peace," Christophine's hybridity makes her doubly marginalized; as Jamaican black creole, she is an outsider in her French colonial inheritance and in her maintenance of African religious practices. Rhys's ambiguous portrayal of Obeah further problematizes the power of Christophine's hybridity. When a neighbor suggests Annette secured her husband through Christophine's Obeah the rumor initially holds more power over Antoinette than the Obeah itself: "She [the neighbor] said it mockingly, not meaning it, but soon other people were saying it-and meaning it" (p. 18). Despite Antoinette's use of "other people," shortly thereafter she sits in Christophine's room frightened: "No one had ever spoken to me about Obeah—but I knew what I'd find if I dared to look. Then Christophine came in smiling and pleased to see me" (p. 18). Antoinette's failure to fear Obeah until she hears the white creole's rumor, reveals the diminished power of Christophine's African identity, even from the perspective of the child she has raised. In contrast to Dominga De Adviento's role as syncretic healer, Rhys's hybrid Obeah practitioner is treated with an ambivalent narrative that accepts, if not reinforces preconceived notions of the limits of the African Other.

Like García Márquez's depiction of Sierva María, Rhys's depiction of Antoinette relies upon the strategy of racial subversion to indicate the shifting boundaries of racial difference as foundational to the protagonist's white creole identity. Despite her closeness to Christophine, Antoinette exists in the liminal space between white colonial and black creole worlds, but never successfully integrates into either. When Antoinette loses a bet while diving in a swimming hole, she calls her friend Tia, a young black girl, "a cheating nigger." Tia in response says to Antoinette: "black nigger better than a white nigger" (p. 14). Like Sierva María's performance of Africanness in Of Love and Other Demons, Rhys's depiction of this exchange subverts racial categories through what Halloran (2006) argues is "a rhetorical exercise in reconfiguring black-white relations in the wake of emancipation" (p. 88). This rhetorical exercise demonstrates that racial constructs, like the language that reflects those constructs, shift within the postcolonial world, yet Rhys's ambivalent treatment of those shifts suggests the impossibility of hybridity or racial subversion as tools to 'heal' the irrationality created by past participation in slavery. More interesting still, Rhys's depicts Christophine as setting limits to Antoinette's white creole identity, despite Christophine's own hybridity. The performative power of Antoinette's racial subversion concludes with Antoinette wearing Tia's dress after her dress had been taken. When Antoinette arrives home, Christophine blames Antoinette's "wild" appearance on her mother's apathy, but also demonstrates ambivalence towards racial subversion through her insistence that they "burn" the clothes (p. 15). Christophine then restores Antoinette's white creole identity when she dresses her in more appropriate clothing. Rhys's depiction of Christophine's agency subverts the notion of the obedient servant when she chastises Annette, but only in order for her to later return Antoinette to her proper place as a civilized white creole daughter. None the less, Christophine demonstrates her ability to inscribe the limits of white and black creole identity in this scene, and in doing so asserts the power of former slaves to establish the conventions of Caribbean identity within the newly emancipated Jamaica.

7 Patois is a Creole language with West African roots spoken in Jamaica. 
In contrast, Antoinette only gains understanding of the limits of her postcolonial identity after a group of emancipated slaves burn down her home. As they flee, Antoinette sees Tia and runs to escape her white creole identity: "I will live with Tia and I will be like her. Not to leave Coulibri" (p. 27). Tia throws a rock at her and rejects Antoinette's attempt at blackness. Due to her previously privileged status, Antoinette cannot see that her racial category has been fixed through slavery. The scene shatters Antoinette's identification with the black creole Other as established through her relationship with Tia and Christophine, and she falls ill. As is the case with Sierva María, Antoinette cannot reconcile her own identity with that of the racial Other with whom she has been raised, and her removal from that racial Other precedes illness. Her illness in this case serves as metaphorical penance of the white creoles of the Caribbean, who both defined themselves in relation to and opposition to the black creole. In this way Antoinette's illness reveals that liminality does not imply an ability for the white creole to transgress the racial fixity established by the colonial history of the Caribbean-merely an ability to exist between such fixed poles. Again, through Antoinette's performance of racial subversion, Rhys reveals that the hybridity of the Jamaican world cannot be accessed by the white creole due to her historical role in slavery. Through Tia, Rhys reinforces the fixity of race for those of European descent, but just like Christophine, Tia disrupts the idea that only the white population can circumscribe the limits of that racial fixity.

With her home destroyed and mother incapacitated by mental illness, Rhys's protagonist, like García Márquez's Sierva María, is taken from her home and sent to a convent that while utilizing a different process, equally prepares Antoinette for colonization and eventual death. While García Márquez's convent cures Sierva María's rearing by black slaves through exorcism for the purpose of salvation, Rhys's convent cures Antoinette's rearing by black creoles by education for the purpose of a financially rewarding marriage. Separated from Christophine, Antoinette learns about the Bible, but she struggles with its contradictions; she learns of hairstyles and calm temperaments, and she receives gifts of clothing from her stepfather. These gifts reveal his desire to improve upon her liminal condition through her performance of colonial identity; the colonizing nature of the act is emphasized when her stepfather visits the convent in order to assess Antoinette as a prospect for the son of an English friend. Antoinette, feels discomfort as he "holds [her] at arm's length, looking at [her] critically" (p. 35). As Olaussen (1993) has pointed out, Antoinette's experience in this marriage recreates the experience of the slave in this physical assessment, subjugation and eventual removal from her place of origin. Just as García Márquez does with his exorcism of his white creole protagonist, Rhys's appropriates the colonial experience of the slave and reenacts that experience upon the white female creole body. Despite Antoinette's fixed white creole identity, this moment suggests the parallel experiences of disempowerment in slavery and disempowerment through patriarchal structures of colonial society. Such a comparison reminds the reader of the role of patriarchy in the propagation of the colonial hegemony, but also prepares the reader for the absolute disempowerment that precedes Antoinette's final descent into madness.

Rhys emphasizes the role of patriarchal control as an aspect of colonial structures in her depiction of Antoinette and her British husband honeymooning on The Windward Islands in anticipation of their move to England. In contrast to Antoinette's liminality, her husband's fixed notions of place and identity at times literally make him lost in the hybrid space of the Caribbean. Like the colonizing Bishop from Of Love and Other Demons, Antoinette's husband fails to function in the hybrid world. This failure is first displayed through physical illness and then through mental illness-all displayed through paranoid, melancholy, and inconsistent, yet authoritative colonial perspective that we view through his first person narrative in this section. As insecure outsider, this narrator asserts power by emphasizing Antoinette's status as liminal Other due to her inability to "think or feel as [he] did," but also due to what he sees as an unnatural affection demonstrated through Antoinette's hugs and kisses with Christophine and the other black creoles. "I wouldn't hug and kiss them," he explains (pp. 54-55). His paranoia is peaked by Antoinette's nighttime contemplations of death-which he soon conflates with sexual encounters that lend her agency. The narrator claims to watch her "die," 
"in [his] way not hers," utilizing his colloquial conflation of orgasm and death. And when she becomes "eager" for sex, thus asserting her own power and enjoyment in the act, he fears his loss of power even more (p. 55). The narrator's desire to control his wife reenacts the colonialist need to be sole author of the identity and actions of the colonized Other, and his feelings of distain for his wife's enjoyment reveals his fear that sex might be the tool through which she as liminal Other corrupts, contaminates, and controls his European body. Rhys's depiction of Antoinette's husband, like that of the Bishop in Of Love and Other Demons, reflects a fear of the contagion of the Other in the contact zone of the Caribbean-and like García Márquez, Rhys places that hypocritical fear within the voice of the diseased colonizer to delegitimize his colonial positioning.

Near the conclusion of their time on the Windward Islands, Rhys once again reveals Antoinette as liminal subject attempting at racial subversion, this time through her act of seeking guidance from Christophine. Unable to control the liminal nature of his wife, nor her sexual drive, Antoinette's ill and drunk husband wanders off and finds himself literally lost again in the forest. Upon his return, he reads a colonial description of Obeah, which becomes his explanation for his getting lost and losing control in general. His failure to see his own illness and drunkenness as the cause for his lack of control parallels Bernarda's failure to recognize her cacao consumption as cause for her illness. Both characters fear the power of the African Other in the black creole (and by proxy their wife and child), but also blame that African Other for their own failures to successfully navigate their worlds. Still, Mardorossian (1999) argues the problematic nature of reading Obeah as powerful syncretic practice within the novel: "the power of Obeah in the novel is not given through its impact upon the black and mulatto community, but paradoxically though the fear and paranoia a stereotypical and colonialist definition produces in Rochester" (p. 1080). Mardorossian (1999) claim however fails to recognize the healing power that the white creole Antoinette attaches to Christophine's magic when she requests a love potion for her husband, in what Mackie (2006) describes as "a misguided attempt" to use "black magic" in order "to become [through her improved relations with her husband] more white" (p. 192). Ironically, through this subversion and because of the narrator's "stereotypical idea of Obeah," Antoinette's use of African practices has aligned her with the racialized Other-an alignment that her husband perceives as sign of contamination, and evidence of the madness he fears exists in Antoinette. Through his conflation between his wife's "Otherness" and her sexuality after this occurrence, Rhys's narrator reveals an irrational fear of miscegenation; for if Antoinette has contracted blackness through her exposure to Christophine, he too might contract blackness (and madness) through sexual encounters with his wife. Miscegenation, like African languages in Of Love and Other Demons, becomes a symptom of the breakdown of binary designation of the racialized Other in both slavery and British colonization. When her husband has sex with a black servant out of revenge for Antoinette's use of Obeah, the hypocrisy of his irrational fear manifests; yet this act of vengeance also ensures Antoinette's slippage from assumed to true madness.

It is through his assertion of Antoinette's madness, one for which he was the true cause, that he achieves a second marginalization of Antoinette. Once the narrator named Antoinette as (mad) Other, he uses this madness to justify Antoinette's removal from her home. In the mind of the narrator, Antoinette must be destroyed to prevent his infection, but first Antoinette's access to the source of her infection must cease; thus the narrator dismisses Christophine upon a threat to jail her based upon her illegal use of the Obeah he fears. While Christophine fights to stay with Antoinette, eventually she backs down, a move Mardorossian (1999) sees as evidence of her inability to assert power over the narrator. It is worth noting however that Christophine does get the final words of this exchange. When Rochester tells her she may write to Antoinette, Christophine responds: "read and write I don't know. Other things I know" (p. 97). In her claim, she disrupts the tools of the colonial narrative. For reading and writing produce Letters of Law, those letters by which he has threatened her. In her response, she shows her intentional failure to embrace the tools of the master and instead asserts her power in the unsaid, a tool she uses to imply her threat through the characteristic ambiguity of the Caribbean and the Obeah that the narrator fears. While this moment reveals Christophine's 
willingness to subvert notions of the subservient Other, in the space of the novel, her threat does not manifest, and we are left with Christophine returning to the garden left to her by Antoinette's mother, her reward for her role as salvation to those people from that diseased culture that once enslaved her.

In the absence of Christophine, Antoinette's husband justifies her imprisonment through his assertion of her madness. Antoinette, like Sierva María without becomes only the (mad) Other and as a result finds herself locked away-though for Antoinette her prison lies in England across the Atlantic Ocean. Olaussen (1993) points out that in her journey across the Atlantic and later imprisonment, "Rhys invites a comparison between Antoinette's situation and that of the slaves" (p. 79). Ironically, it is in her journey west, which mirrors her narrative to that of the historical black creole, that she most fully accomplished racial subversion, in the complete denial of power and absolute subjugation of her white creole body, her liminal Other; but in her journey she does not mirror the emancipated slaves from whom she sought community in Jamaica and the Windward Islands, but instead the captive slaves upon whose bodies those colonial societies were built. Renamed Bertha and dispossessed of agency and identity in her husband's tower, Antoinette delivers a disconnected first person narrative in the final section of the novel. Like the Church's efforts to control Sierva María's perceived possession, her husband's efforts to control Antoinette's perceived madness cause a progression into true mental illness. Through her depiction of Antoinette's descent, Rhys condemns her white creole-who unlike the black creole of the story cannot seek hybridity nor transcend racial fixity to successfully navigate her world.

Despite what the reader, steeped in the colonial framework established by Bronte knows to be the white creole woman's demise, Antoinette's narrative concludes with a dream sequence in which she in which she finds power through her attachment to the black creoles from her liminal life across the ocean. Within the dream, Antoinette calls out to Christophine "help me," and "she is helped" (p. 112). As Antoinette hears the voice of her husband calling out her colonized name of Bertha, she instead turns to Tia's voice calling on her to be brave, and she contemplates jumping from her high window in her prison, wondering if she would not take flight, and realizing that flight might take her home. Now in a dream implying yet another act of racial subversion, Antoinette debates her participation in the decolonizing flight back home-an image steeped in symbolism of the African Other ${ }^{8}$, but this triumph is only a dream. Antoinette's fate, like that of Sierva María, is death-though Antoinette determines her suicidal leap-that we know of from Bronte's novel. But Rhys chooses not to depict that leap. Instead, she leaves the reader in the dream, which reflects a desire for the white creole with the help of the black creole to escape into the known of her liminal space, but not the ability. Like Christophine's subversion in her closing threat, Antoinette's dream cannot manifest.

\section{Conclusions}

While the authors of Of Love and Other Demons and Wide Sargasso Sea critique colonialist structures through their depiction of the mental and physical illness of colonial society and the potential for wellness found in the African Other of the Caribbean, the contrasting fates of the white protagonists and black nurse mothers imply a that such progress only occurs in the acquisition of whiteness. For while the black creole's progression beyond racially fixed hegemony can be successfully navigated through the slaves' and former slaves' adoption/adaptation of Catholicism and other tools of the white world, the white creole bodies that try to find well-being through an attachment to their African influences fail in death. This failure reinforces notions that the infection of blackness on the white body causes devaluation of that white creole body. In this way, these two novels suggest the only successful hybridity requires the adaptation to whiteness, for racial subversion through the acquisition of blackness means death. In doing so, the authors critique, but fail to fully subvert the racial hierarchy upon which the institution of slavery is built.

8 Africans who were part of the diaspora created by the Transatlantic slave trade, developed specific mythologies of human flight. Some of those stories communicated flight as a path back home across the Atlantic to Africa (McDaniel 1990). 
The parallel fates of the diseased aristocratic societies, the syncretic healers, and the white creole protagonists attempting at blackness in these two novels demonstrate the potential for exploring shared narratives across literatures steeped in the postcolonial histories of oblivion in the New World. In the case of these two novels, the parallels reveal the impact that a shared history of slavery has had and continues to have on the formation of both white and black creole narratives of the Caribbean. More specifically, the texts point to the historical impact of slavery on the formation of black and white creole identity and reinforce narratives that suggest that through the historical ownership of the black body, the navigation of whiteness has always been part of establishing New World identity of blackness-in these novels divorcing from this paradigm proves impossible for even the most disruptive of Others. In contrast, the novels' white population fails to reconcile the racial Other as part of the formation of white creole identity in the Caribbean, and the protagonists' death points to that failure as irrational and destructive in light of in undeniably hybrid and evolving world. In both of these cases, the theme of perceived irrationality and provoked madness serves to further emphasize the irrationality of the myth of racial binaries and the system of slavery upon which that myth was built; yet the novels' problematic presentation of an idealized hybridity of the black creole and boundaries of hybridity and racial subversion in the white creole show the limits of the author's critiques of colonialism. Despite these limits, the shared progression of these characters reveals an impetus to reimagine and revisit narratives in the region of the Caribbean where the "forces and fixities" continue to evolve in response to a common history of slavery's oblivion.

Wide Sargasso Sea's 1966 publication date followed only four years after Jamaica declared their independence from British rule; this shift in the postcolonial structures of Jamaica would allow for yet another opportunity to reimagine this hybrid space, and Rhys's novel in many ways anticipates the efforts to rewrite and reimagine new narratives of black, white and hybrid Caribbean identities in this newly independent nation. Of Love and Other Demons 1995 publication coincided with one of the most violent decades of 50-year war between Columbian guerillas and the government. In García Márquez's reimagination of Caribbean identity, the irrational, violent and fatal conclusion of the novel seems fitting in a nation that seemed to never escape the violence of its own formation or its irrational distribution of power. Despite these novels' ultimate failure to subvert the racial constructs created over 500 years ago to justify the enslavement of over eleven million Africans ${ }^{9}$, the historical settings and contemporary contexts point to constant evolution in postcolonial realities that continues to provide authors new contexts in which to reimagine and reform Caribbean identity, historical narratives, and power structures in the New World.

Funding: This research was funded by an Aurora University Faculty Development Research Grant.

Conflicts of Interest: The author declares no conflict of interest.

\section{References}

Bhabha, Homi. 2004. The Location of Culture, 2nd ed. New York: Routledge.

Cass, Jeremy L. 2009. Race and Resistance in Del Amor y Otros Demonios. Latin Americanist 53: 49-70. [CrossRef] García Márquez, Gabriel. 1995. Of Love and Other Demons. Translated by Edith Grossman. New York: Penguin Books. Halloran, Vivian Nun. 2006. Race, Creole, and National Identities in Rhys's 'Wide Sargasso Sea' and Phillips's 'Cambridge'. Small Axe: A Caribbean Journal of Criticism 10: 87-104. Available online: http://search. ebscohost.com/login.aspx?direct=true $\& \mathrm{db}=\mathrm{a} 9$ h \&AN=23130761\&site=ehost-live\&scope=site (accessed on 15 March 2015). [CrossRef]

9 Despite historians estimates that have reached as high as 50 million, this number represents the current best estimate based on the historical records we can find about the Transatlantic slave trade given the processes of oblivion implied by slavery ("Africa's Losses", in The Story of Africa-Slavery. London: BBC World Service. Available online: http:/ /www.bbc.co.uk/ worldservice/africa/features/storyofafrica/9chapter6.shtml, accessed on 3 November 2018). 
Handley, George B. 2004. A New World Poetics of Oblivion. In Look Away! The U.S. South in New World Studies. Edited by Jon Smith and Deborah Cohen. Durham: Duke University Press, pp. 25-51.

Jaising, Shakti. 2010. Who Is Christophine? The Good Black Servant and the Contradictions of (Racial) Liberalism. Modern Fiction Studies 56: 815-36. Available online: http:/ / search.ebscohost.com/login.aspx?direct=true\& $\mathrm{db}=\mathrm{a} 9 \mathrm{~h} \& \mathrm{AN}=59734598 \&$ site $=$ ehost-live\&scope=site (accessed on 18 March 2015).

Mackie, Erin. 2006. Jamaican Ladies and Tropical Charms. Ariel 37: 189-219. Available online: http:/ / search.ebscohost.com/login.aspx?direct=true\&db=a9h\&AN=26155573\&site=ehost-live\& scope $=$ site $\backslash \mathrm{T} 1 \backslash$ textgreater \{\} (accessed on 15 March 2015).

Mardorossian, Carine Melkom. 1999. Shutting up the Subaltern: Silences, Stereotypes, and Double-Entendre in Jean Rhys's Wide Sargasso Sea. Callaloo 22: 1071-90. Available online: http:/ /www.jstor.org/stable/3299872 (accessed on 18 March 2015). [CrossRef]

McDaniel, Lorna. 1990. The Flying Africans: Extent and Strength of the Myth in the Americas. Nieuwe West-Indische Gids/New West Indian Guide 64: 28-40. [CrossRef]

Olaussen, María. 1993. Jean Rhys' Construction of Blackness as Escape from White Femininity in Wide Sargasso. Sea Ariel 24: 65-82. Available online: https://journalhosting.ucalgary.ca/index.php/ariel/article/view / 33577 (accessed on 18 March 2015).

Paton, Diane. 2015. The Cultural Politics of Obeah. Cambridge: Cambridge University Press.

Penuel, Arnold M. 1997. Symbolism and the Clash of Cultural Traditions in Colonial Spanish America in García Márquez's Del amor en otro demonios. Hispania: A Journal Devoted to the Teaching of Spanish and Portuguese 80: 38-48. [CrossRef]

Puri, Shalini. 2004. The Caribbean Postcolonial: Social Equality, Post/Nationalism, and Cultural Hybridity. London: Palgrave Macmillan.

Rhys, Jane. 1999a. Wide Sargasso Sea. Edited by Judith L. Raiskin. New York: Norton Critical Edition. First published 1966.

Rhys, Jane. 1999b. Selected Letters. In Wide Sargasso Sea. Edited by Judith L. Raiskin. New York: Norton Critical Edition. First published 1966.

Said, Edward W. 1978. Orientalism. New York: Random House.

Spivak, Gayati Chakravorty. 1985. Three Women's Texts and a Critique of Imperialism. Critical Inquiry. 12: $243-61$. [CrossRef]

Utley, Gregory. 2011. Exorcism, Madness, and Identity in Gabriel García Márquez's Del Amor Y Otros Demonios. Hispanofila 162: 79-90. [CrossRef]

Vásquez-Medina, Olivia. 2013. Reading Illness in Gabriel García Márquez's Del Amor y Otros Demonios. Modern Language Review 108: 162-79. [CrossRef]

(C) 2019 by the author. Licensee MDPI, Basel, Switzerland. This article is an open access article distributed under the terms and conditions of the Creative Commons Attribution (CC BY) license (http://creativecommons.org/licenses/by/4.0/). 